\title{
The Double-Edged Sword of Independence: Inoculating Electoral Reform Commissions Against Everyday Politics
}

\author{
HEATHER K. GERKEN
}

W HEN ACADEMICS AND POLICYMAKERS talk about what ails American politics, many offer a similar diagnosis: the problem is that we leave the regulation of politics to politics; elected officials set the rules by which they are elected. Unsurprisingly, the proposed cure to this problem is often to create an independent body to set the rules, insulating its members from the distorting effects of special interest politics. ${ }^{1}$ As Michael Kang writes of the problem that has most recently captured critics' attention-the fact that legislators draw their own districts - there is an "understandable impulse to retreat from the political process."2 Proposals for independent districting commissions abound in the scholarly literature and reform blueprints. ${ }^{3}$ Most of these proposals offer a technocratic solution: a commission composed of neutral experts. ${ }^{4}$ A handful ${ }^{5}$ are mod-

Heather K. Gerken is Professor of Law at Yale Law School. For helpful comments and suggestions, the author thanks Rachel Barkow, Rick Hasen, Daryl Levinson, Dan Lowenstein, Rick Pildes, Ben Shultz, Dan Tokaji, two anonymous reviewers, and the participants in the Workshop on Citizen-Designed Democratic Processes sponsored by the University of British Columbia and the conference on Independent Election Administration sponsored by the Moritz College of Law at Ohio State University. These ideas have been explored in quite abbreviated form in an editorial that appeared in Roll Call, Heather Gerken, "Citizens Must Drive Electoral Reform," Roll Call, Nov. 15, 2005, and in a blog entry co-authored with Chris Elmendorf, <http://balkin.blogspot.com/2005/11/next-timestart-with-people.html > (last checked Dec. 19, 2006), to whom the author is especially indebted for conversation and critique. Thanks to Brian Choi, Paige Herwig, Ben Shultz, and Damian Williams for excellent research assistance. eled on the British Columbia Citizens' Assembly, composed of 160 randomly chosen citizens who deliberated for several months and proposed a new system for electing candidates in

${ }^{1}$ I term these bodies "electoral reform commissions." There are, of course, at least two types of functions that such decision making bodies could serve: a legislative function (proposing or setting the basic rules that govern elections) and an administrative one (the day-to-day running of elections). This article focuses solely on the former and uses the term electoral reform commissions to make clear that I am talking about institutions charged with recommending changes as to how our election system is run rather than with implementing those requirements, once enacted. For further description, see infra Section I.B. For analysis of the use of independent agencies to administer election laws once enacted, see Richard L. Hasen, Beyond the Margin of Litigation: Reforming U.S. Electoral Administration to Avoid Electoral Meltdowns, 62 Wash. \& Lee L. Rev. 937 (2005).

${ }^{2}$ Michael S. Kang, De-Rigging Elections: Direct Democracy and the Future of Redistricting, 84 Wash U.L.Q_ (forthcoming 2007). Kang's paper is devoted to a question not addressed here-how much public involvement should there be in setting the background rules of politics-and argues that we should use direct democracy to foster greater public engagement in the process. For another, quite different analysis of this question, see Dennis F. Thompson, Who Should Govern Who Governs? The Role of Citizens in Reforming the Electoral System (unpublished draft, 2005).

${ }^{3}$ Consider what has appeared in the Harvard Law Review alone in the last few years. See Samuel Issacharoff, Gerrymandering and Political Cartels, 116 Harv. L. Rev. 593, 641 (2002); Richard H. Pildes, Foreword: The Constitutionalization of Democratic Politics, 118 Harv. L. Rev. 28, 78-83 (2005). Reform groups, including heavy hitters like Common Cause and the League of Women Voters, have similarly endorsed independent districting commissions. <http:// www.commoncause.org/site/pp.asp?c =dkLNK1MQIw $G \& b=196481>$ (last visited Sept. 5, 2006); <http://www. campaignlegalcenter.org/redistricting-223.html> (Report at 41) (last visited Sept. 5, 2006). 
the province for approval via referendum. ${ }^{6}$ This article addresses those who are attracted to such institutions because they desire independence ${ }^{7}$ - a chance to shut self-interested legislators, special interest groups, and political parties out of the decision making process, or at least to minimize their influence over the relevant decision makers.

The modest point of this article is that independence is a double-edged sword. I do not seek here to quibble with the basic impulse behind proposals for reform. Nor do I offer what has by now become the conventional response to calls for independence-the argument that true political independence is impossible to achieve. Instead, granting reformers' claim that independence can be had, I query whether one can have too much of a good thing. Giving electoral reform commissions too much independence from politics may, ironically, undermine the success of reform efforts in the long run. Independence, in short, has costs as well as benefits: it gives the decision maker credibility to speak, but it creates the risk that the content of the speech will never become a reality.

The solution to the problem of political infection, then, is not to quarantine electoral reform commissions from everyday politics, ${ }^{8}$ but to inoculate them. Inoculation, of course, requires one to be infected by the very virus one seeks to avoid. My proposal is thus to infuse the decision making process with some of the concerns that dominate everyday politics. Indeed, while scholars and policymakers of all stripes tend to express disdain for politics, I wish to argue that reform efforts can fail because they do not involve enough politicking.

The article proceeds as follows. Part I describes the empirical justification for inoculating electoral reform commissions against politics. It begins by describing and defending the key assumption underlying the article-that most reform will involve an iterated process that requires a proposal to win legislative or popular approval in order to be implemented. The dilemma for reformers, then, is that they must play politics in order to change the way politics ultimately will be played. This Part then examines a small but burgeoning literature on the institutional structures that are most likely to achieve reform in areas where law and politics intersect. Although that literature is too embryonic to draw firm conclusions, it suggests that fully independent decision making bodies can sometimes be less effective at achieving reform than institutions that are at least partially enmeshed within the political system. Independence, counterintuitively enough, can sometimes insulate decision makers from political pressures to such an extent that they lose sight of what type of reform is politically realistic. Moreover, political elites can play a crucial role in ensuring that public support for reform runs wide as well as deep, and it is politically connected reform commissions that have a better chance of gaining the support of such elites.

Part II offers a first cut at the more difficult question raised by this article: how do we strike the proper balance between political infection and political quarantine? It argues that any inoculation strategy must be tailored to the type of institution in question. Independent commissions dominated by technocratic elites may be handicapped in systematically different ways than citizens' assemblies in devising and helping pass sensible reform. Because any such analysis depends heavily on context, this sec-

\footnotetext{
${ }^{4}$ Supra sources in note 3.

${ }^{5}$ Infra text accompanying notes 14 to 16 (noting the states and countries which have established or are considering establishing a citizens' assembly).

${ }^{6}$ See < http://www.citizensassembly.bc.ca/public > (last visited Sept. 5, 2006); see also infra Section II.B.

${ }^{7}$ As Chris Elmendorf has helpfully pointed out, the word independence has many meanings: sometimes it refers to formal, de jure structures protecting a decision making body from politics (e.g., whether it can exercise power unilaterally, whether its membership is beholden to other political bodies, whether it is insulated from retaliation); other times it conveys a de facto removal from politics. For these purposes, I generally mean to use the word in its colloquial sense, to refer to de facto distance or aloofness from politics. In using the term in this way, however, I do not mean to downplay the fact that these meanings are often closely intertwined in practice. After all, a body with formal rulemaking independence or protection from political retaliation is more likely to be "independent" in the colloquial sense than one that is institutionally beholden to political actors in some way. And the purpose of this article is to examine formal and informal design strategies that would encourage electoral reform commissions to pay adequate attention to political concerns. ${ }^{8}$ I use the phrase politics here in its colloquial (and thus negative) sense to refer to a political system marked by partisanship and special interests.
} 
tion of the article will not offer a full-blown account of every institutional mechanism one might employ to inoculate a given electoral reform commission. Instead, it will use the recent experience of the British Columbia Citizens' Assembly as a case study in order to offer a few, tentative suggestions about how to strike the appropriate balance between political engagement and political independence.

\section{INDEPENDENCE AS DOUBLE-EDGED SWORD}

\section{A. The dominance of the independence model}

It is not surprising that so many scholars and policymakers are attracted to the independence model in thinking about how to design electoral reform commissions. For scholars attracted to the deliberative model, independence allows citizens to retreat from everyday politics to think through the difficult problems before them. Insulated from the pressures of partisan politics and self-interested lobbying, discussion can take place on the terms that many deliberative democrats believe confer legitimacy on the outcome. ${ }^{9}$ Even public choice scholars-who pride themselves on taking a more clear-eyed view of politics than their idealistic academic brethren-tend to favor independent decision making. While public choice scholars always worry about the problem of capture, independent commissions seem less vulnerable to the influence of special interests than legislatures. The case is even easier with regard to electoral commissions, where those most tainted by self-interest are the legislators themselves. ${ }^{10}$

Policymakers also seem to favor the independence model. U.S. reformers have repeatedly proposed independent commissions composed of retired judges or technocrats for drawing district lines, and not a year goes by without some blue ribbon panel of experts suggesting how we can improve our democracy. Similarly, the decision by two Canadian provinces and the Netherlands to create assemblies composed of average citizens to deliberate about reform seems to embody a desire to avoid the distorting effects of special interest groups, party politics, and legislative self-interest and thus "align the interests of [decision makers] with those of the citizens."11

The benefits of independence are so obvious that one would think that almost anyone could agree as to its virtues. It offers all the attractions of intellectual purity: objectivity, the chance to vindicate the public interest rather than special interests, an opportunity to avoid the unappetizing brew of watered-down reform. But notice that the easiest case to be made for independence concerns its outputs; most are

9 See Dennis F. Thompson, Just Elections 168-79 (2002) (endorsing deliberative electoral reform commission); see also Cass Sunstein, Beyond the Republican Revival, 97 Yale L.J. 1539, 1549 (1988) (arguing that those who favor civic republicanism-a historically influenced normative account in favor of deliberation favored by many law professors-will "attempt to insulate political actors from private pressure"); id. at 1560 (arguing that even elected representatives should enjoy "substantial autonomy"); Michael A. Fitts, Look Before You Leap: Some Cautionary Notes on Civic Republicanism, 97 Yale L.J. 1651, 1653 (1988) (on reviewing the civic republicanism literature, concluding that its "most important structural goal appears to be political insulation"). For a less sanguine view of the role that political insulation plays in fostering healthy deliberation, see Amy Guttman and Dennis Thompson, Democracy and Disagreement 45-47, 128-64 (1996).

${ }^{10}$ The most recent and powerfully articulated variant of this argument is made by Sam Issacharoff. See Issacharoff, supra note 3. For a spirited response, see Nathaniel Persily, In Defense of Foxes Guarding Henhouses: The Case for Judicial Acquiescence to Incumbent-Protecting Gerrymanders, 116 Harv. L. Rev. 649 (2002).

11 The phrase comes from an anonymous reviewer. Interestingly, even the participants in the BC Citizens' Assembly seemed to value the Assembly's insulation from party politics. For instance, when members of one political party, the Greens, tried to lobby the Assembly, the strategy backfired, as members of the Assembly resented the Greens' effort to influence the decision making process. See Glenn Bohn, Greens won't endorse but like electoral reform, Vancouver Sun, May 3, 2005, at A5 (according to Green Party leader, "the citizens' assembly wanted every party neutral ... they didn't want political interference"); R.S. Ratner, The B.C. Citizens' Assembly: The Public Hearing and Deliberations Stage, Canadian Parliamentary Review 27 (Spring 2005) (noting that Assembly participants expressed concerns about the "infiltration and dominance of special interest groups into the hearings and submission processes"). According to one report, the Green Party's use of a common political tool-"bombard[ing] the assembly with hundreds of identical submissions"ended up "provoking a backlash" from some members of the Assembly. Vaughn Palmer, Vote on electoral reform not necessarily the last word, James says, Vancouver Sun, April 6, 2005, at A3. 
ready to trust the results of a decision making process shielded from partisan politics.

\section{B. The institutional terrain for reform}

In thinking about how best to design electoral reform commissions, however, we ought to think not only about the quality of their outputs, but the likelihood that their recommendations, once offered, will actually be put into practice. Even if we can all agree that independent decision makers will have good judgment about what ought to be done, will they actually get it done?

To evaluate that question, of course, we must know what the institutional terrain looks like, and this brings me to the underlying premise of the article: reform proposals will at some point have to be tested on the turf of everyday politics. It would be simple, of course, if reform commissions were like Athena and thus sprang, fully formed, from the head of a god. After all, if we hypothesize a commission that is independent in every sense of the word-beholden to no one and able to rule unilaterally in the area of electoral reform-concerns about the commission's ability to get things done would fall away.

When we move from the ideal to the real world, we discover that reform is usually an iterated process; reform commissions generally must win legislative or popular approval for their recommendations to be implemented. That is obviously true of privately created blue ribbon panels. But even if we look to state-created reform commissions, they tend to be the product of compromise and thus vested with similarly limited powers. ${ }^{12}$ In the strong variant, such commissions are given formal agenda setting power, with their proposals guaranteed a vote. In the weaker variant, commissions are vested with the authority to make recommendations only. Examples of state-created commissions with powers limited in this fashion abound. The oft-cited American example of a nonpartisan districting commission, Iowa's, follows this model. This is how districting commissions and electoral reform commissions function in Canada, Australia, and the United Kingdom. ${ }^{13}$ And this is how the newest variant of the reform commission, the citizens' as- sembly, worked in British Columbia and will work in Ontario, ${ }^{14}$ and perhaps other places, such as the United Kingdom ${ }^{15}$ and California. ${ }^{16}$

Nor is it surprising that so many real-world examples of state-created electoral commissions function in this way. As a practical matter, electoral commissions must be put in place by somebody, usually a legislative somebody. In the unusual case where political pressures become so great that politicians feel the need to do something reform-minded, this type of democratic check on a nominally independent commission's power is likely to be a more attractive option to legislators than ceding full control to the commission. ${ }^{17}$ After all, although an iterated process may grant agenda-setting power to the commission, it nonetheless allows legislators to reject reforms they cannot stomach. Reform proposals must also withstand democratic scrutiny if one follows the model of the B.C. Assembly, whose proposals would become law only if approved via referendum. ${ }^{18}$

12 In the words of one study, "electoral systems are rarely designed; they are born kicking and screaming into the world out of a messy, incremental compromise between contending factions battling for survival, determined by power politics." Pippa Norris, Introduction: The Politics of Reform, 16 Intl. Pol. Sci. Rev. 3, 4 (1995).

${ }^{13}$ Christopher S Elmendorf, Representation Reinforcement Through Advisory Commissions: The Case of Election Law, 80 NYU L. Rev. 1336, 1386-94 (2005). The Netherlands Citizens' Assembly will follow this model as well. <http:// snider.blogs.com/citizensassembly/2006/03/update_fro m_net.html> (last visited Aug. 24, 2006).

${ }^{14}$ Ontario to appoint citizens assembly on election reform (press release, FairVote Canada, Nov. 18, 2004).

${ }^{15}$ Daniel Forman, "Call for citizens' assembly on electoral system," ePolitix.com (Aug. 4, 2005).

${ }^{16}$ Editorial, "Where politicians dare to tread," San Francisco Chronicle (June 18, 2006).

${ }^{17}$ In New Zealand, for instance, the government set up an electoral reform commission "only because it was felt to pose no threat," since "its findings could always be shunted, if necessary, to obscurity in a parliamentary committee." David Denemark, "Choosing MMP in New Zealand: Explaining the 1993 Electoral Reform," in MixedMember Electoral Systems: The Best of Both Worlds? 70, 85 (eds. Shugart and Wahenberg, 2001).

${ }^{18}$ Consistent with the assumption that even politicians pressured into creating an electoral reform commission will do what they can to undermine its chances of success, it is worth noting that even the B.C. government, which created the first citizens' assembly, could not resist imposing a fairly high bar on reform, requiring a $60 \%$ province-wide vote as well as support across B.C.'s ridings for the measure to pass. See infra text accompanying 
One might think that there is an easy strategy for creating a commission that can mandate, rather than merely propose, reform: the initiative process. If legislators are unwilling to create a fully independent commission, reformers should simply take their case directly to the people. Even there, however, political elites can wield considerable influence. Assessing reform proposals, of course, is a difficult task, one that few voters have the time or energy to do. They thus rely on cues in casting their vote, and those cues are often provided by the political parties and other democratic elites. Not only can politicians mobilize popular support, they can affect voters' decisions merely by taking a public stand.

The problem, of course, is that the group best able to provide political cues and mobilization in support of reform-the party in power-will almost always oppose reform. And if the majority party opposes reform, there is a good chance that so too will the majority of citizens. ${ }^{19}$ Consider, for instance, what recently took place in California and Ohio, where reformers tried to create nonpartisan districting commissions via referenda. Despite public support for redistricting reform, both referenda failed. ${ }^{20}$ The most likely explanation is that voters were relying on cues in deciding whether the proposals made sense. Democrats, who are in the majority in California, apparently voted against Proposition 77 because it was backed by Republican Governor Schwarzenegger. Similarly, Republicans in GOP-dominated Ohio seem to have voted against Issue 4 because it was backed by a group composed of Democrats and unions. ${ }^{21}$ note 63; Myke Logan, “We still want BC-STV_-Reclaiming Democracy," Common Ground Canada (Sept. 2, 2005) (arguing that the legislature's departure from B.C.'s usual practice on referenda, implementing proposals that gain a simple majority of the vote, was a deliberate effort to scuttle reform). Similarly, New Zealand's National Party, which staged the referenda that led to the country's switch of its election system, deliberately made the process complex (the vote, for instance, was a multi-stage process) in a "not-sosubtle maneuver" to "defeat reform." Jack Nagel, What Political Scientists Can Learn from the 1993 Electoral Reform in New Zealand, 27:3 P.S.: Pol. Sci. \& Pols. 525, 526 (Sept. 1994).

Even if one, in theory, encountered a sufficient concentration of reform-minded legislators willing to create a body that looks fairly independent, the problem of capture remains in the long term. Indeed, there is a cottage industry in administrative law devoted to identifying the many ways in which administrative independence can be undermined by legislative self-interest. Much of this literature builds on the seminal work of the "McNollgast" trio concerning the use of procedural rules and institutional design strategies to control agencies. See Mathew D. McCubbins et al., Administrative Procedures as Instruments of Political Control, 3 J. L. Econ. \& Org. 243 (1987); see also Murray J. Horn and Kenneth A. Shepsle, Commentary on "Administrative Arrangements and the Political Control of Agencies": Administrative Process and Organizational Form as Legislative Response to Agency Costs, 75 Virg. L. Rev. 499 (1989); Jonathan R. Macey, Organizational Design and Political Control of Administrative Agencies, 8 J. L. Econ., \& Org. 93 (1992); Barry R. Weingast and Mark J. Moran, Bureaucratic Discretion or Congressional Control? Regulatory Policymaking by the Federal Trade Commission, 91 J. Pol. Econ. 765 (1983). For a critical and thoughtful response, see Steven P. Croley, Public-Interested Regulation, 28 Fl. St. L. Rev. 7 (2000). For efforts to apply the insights of this literature to the debate over agency independence, see Rachel E. Barkow, Administering Crime, 52 UCLA L. Rev. 715, 730-35, 757, 799 (2005) (documenting the dangers of capture even for independent agencies with lawmaking authority); Elmendorf, supra note 13, at 1379 (based on an analysis of all of the models in the U.S., concluding capture as "a live possibility, if not an inevitability").

19 There are exceptions to this rule, to be sure. In places where anti-party sentiment runs particularly high, a major party's endorsement may do as much to undermine an initiative proposal as to help it. See infra note 41.

20 See Caroline Tolbert et al., Mass Support for Redistricting Reform: Partisanship and Representational Winners and Losers (unpublished draft prepared for the APSA 2006 meeting) (exploring this paradox).

${ }^{21}$ Partisan heuristics are not the sole explanation for the votes (consider the fact that a good number of Democrats voted against the Ohio provisions). Nonetheless, partisan cues were widely available. In Ohio, for instance, critics of the initiative repeatedly branded it as a Democratic power grab. See, e.g., Opinion, "Case Against Issue 4 Takes a Hit," Dayton Daily News, Nov. 3, 2005, at A14 ("From the beginning of the debate about Issue 4, critics have portrayed it as a Democratic effort to take power from Republicans."). Newspapers reinforced these types of partisan cues. For instance, an editorial in the Cleveland Plain Dealer claimed that "[i]t's easy to see why Republicans don't want to see Ohio change the rules that govern political fund-raising, legislative district mapping, elections supervision and political fund-raising. They hold all of the high cards at the moment. . . . It's just as easy to see why the Democrats are dying to change the rules. They're so short of high cards, they've practically been dealt out of the game." Kevin O'Brien, "Reform Ohio Now? No, no, and no," Cleveland Plain Dealer, Oct. 19, 2005, at B11; see also Martin Gottlieb, "Issue 4 is the One that Counts," Dayton Daily News, Oct. 16, 2005, at B8 ("Republican leaders oppose the reform, Issue Four, because they are benefiting from the current system"); Opinion, "Black Leaders OK of Issue 4 Says a Lot," Dayton Daily News, Oct. 12, 2005, at A8 ("[t]he real concern of the opponents of reform is that if the Republicans can't draw 
The California and Ohio examples confirm how difficult it is to put an all-powerful electoral reform commission into place via initiative. These examples suggest that even when the pressure for reform is sufficiently intense to force a change in the status quo, the apparently more palatable, middle-ground approach-an independent commission that can propose but not unilaterally enact election reform-may be more likely to garner the support (or at least avoid the intense opposition) of the legislative elites who can influence the initiative vote. ${ }^{22}$

\section{The costs of independence}

For all of these reasons, whether we are dealing with privately-created blue ribbon panels or state-created commissions, politics is the likely territory through which any reform proposal must pass. ${ }^{23}$ Needless to say, everyday politics can be fairly rocky terrain for those who favor reform. Political elites have significant incentives to oppose change, and voters rarely place electoral reform at the top of the political agenda. The question, then, is how best to design a commission to navigate this political terrain. And there is a small but burgeoning literature suggesting that in this context, where advocates for change face an uphill political battle, the pure independence model may not always be the best one.

Political insulation brings many advantages in the reform process, of course. Independence is a valuable coin in the realm of politics. Political actors of all sorts have discovered the power associated with the perception of neutrality and independence-everyone, it seems, wishes to be a political maverick. We can thus imagine that citizens will give greater credence to the product of an independent citizen's assembly or commission than they would to the decision of elected representatives or the proposals of special interest groups.

Nonetheless, the case for independence is more complex than this conventional account would suggest. Unless popular support for change runs wide and deep, it is hard to push reform through the democratic process. And the maps, there might be fewer Republicans elected"). Similarly, in California, voters had the most obvious of partisan cues, with California's action-star-turned-governor, Arnold Schwarzenegger, supporting the initiative and leading Democrats on the other side. See, e.g., Jim Puzzanghera, "Davis Opposes Reform Initiatives," San Jose Mercury News, Oct. 29, 2005 (quoting California's former governor, a Democrat, on the measure); Carla Marinucci, "Dean Urges Voters to Reject Measures Governor Supports," San Francisco Chronicle, Oct. 17, 2005, at B1 (quoting Democratic heavyweight Howard Dean). Newspapers followed the politicians' lead, linking the governor's proposal to Tom Delay, see, e.g., Jamie Court, "The Secret Force Behind the Propositions," Los Angeles Times, Oct. 30, 2005, at M3, and noting that Republicans were providing significant funding for the measure while many Democrats were supporting the opposition forces. See, e.g., John Wildermuth, "Nonpartisan' Measure Draws Partisan Debate," San Francisco Chronicle, Oct. 27, 2005, at B2; Dan Morain, "Shell Games Hide Source of Donations," Los Angeles Times, Oct. 23, 2005, at B1; Robert J. Caldwell, "Back to the Booth," San Diego Union-Tribune, Nov. 7, 2005, at G1. Post-election assessments provide some confirmation of the importance of partisan cues to the results of the referenda. See, e.g., Lake Research Partners, Redistricting in $\mathrm{CA}$ and $\mathrm{OH}$ (JEHT Foundation 2006), available at $<$ http:/ / electionupdates.caltech.edu/2006/02/whydid-redistricting-reform-fail-in.html $>$ (last visited Feb. $16,2006)$ (documenting dramatic partisan split in refer- enda votes in two states); Tolbert et al., supra note 20 (finding that voters' partisan interests influenced the vote in each state but raising questions about elite influence).

22 Ohio and California's initiative votes, of course, did not involve particular reform proposals but the creation of independent districting commissions, a close analog to the type of electoral commission discussed in this article. Those referenda thus raise the question-not answered here-as to how any commission gets created in the first place. The limited purpose of this article is to think about how best to design the commissions that will eventually be put in place, and the Ohio and California experiences provide some support for focusing this article on commissions whose proposals become law only when vetted via legislative vote or referendum. Elsewhere I have discussed the relevance of these arguments for the prior but obviously related question-how to get electoral reform commissions created in the first place. See Heather Gerken, "Citizens Must Drive Electoral Reform," Roll Call, Nov. 15, 2005; see generally authorities cited infra note 28. Given the limited nature of this essay and the important differences between the two contexts, I leave a fuller exploration of that question for another day.

${ }^{23}$ For an exploration of the inevitable connection between law and politics in a quite different context, the debate over the International Criminal Court, see Richard $\mathrm{H}$. Pildes, Conflicts Between American and European View of the Law: The Dark Side of Liberalism, 44 Va. Int'l L.J. 15, 156-61 (2003). 
there is evidence-too limited at this point to draw firm conclusions-that a pure independence model may not be perfectly suited to produce reform proposals capable of withstanding a run through the political mill.

Consider Rachel Barkow's study of sentencing commissions. ${ }^{24}$ As with electoral reform, those in favor of lower sentences face a difficult political battle, with powerful special interest groups working against sentence reduction and weak political support in favor of lower sentences. In her study of sentencing commissions in the United States, Barkow compares the success of independent and non-independent sentencing commissions and concludes that "the more influential agencies are not those with the greatest insulation from politics, but rather those commissions that are closer to political actors and work within the political culture." 25

Closer to the subject matter is Christopher Elmendorf's exhaustive analysis of advisory electoral commissions. ${ }^{26}$ Based on a comparative study of the United States, Canada, Australia, and England, Elmendorf concludes that the optimal model for overcoming the problem of political entrenchment is not to create a politically insulated constitutional court or regulatory commission but to "augment rather than displace ordinary lawmaking and political contestation" by creating a permanent commission with a solely advisory role. ${ }^{27}$

Finally, consider the studies examining successful voting reform efforts worldwide, ${ }^{28}$ particularly Dennis Pilon's report for the Law Commission of Canada and Fair Vote Canada ${ }^{29}$ and the studies of New Zealand's switch from a first-past-the-post system to a semi-proportional system in 1993. ${ }^{30}$ Although these reports do not focus on the institutional mechanisms most likely to result in reform, they suggest some more general conclusions we can draw about the important role that political parties and interest groups play in generating sufficient support for reform to succeed. ${ }^{31}$

While these studies-and the underlying empirical evidence on which they rely-take quite different approaches in their methodology and analysis, 32 one can discern two common threads in the evidence that seem relevant to the question before us: (1) the value of a po- litical sounding board for reform commissions, and (2) the crucial role elites play in building political support for change. Both suggest that power is associated with what I term political inoculation-the introduction of some politicking into the decision making process itself. While the literature is in too embryonic a stage to draw any firm conclusions, the findings of

24 Barkow, supra note 18.

${ }^{25} \mathrm{Id}$. at 719. Barkow's study synthesizes and is supported by a number of other state-by-state analyses on the relative success of sentencing commissions. See infra text accompanying notes 35 (drawing on some of those sources). ${ }^{26}$ Elmendorf, supra note 13.

27 Id. at 1371.

28 See, e.g., Mixed-Member Electoral Systems: The Best of Both Worlds?, supra note 17, at 55-278: Symposium The Politics of Electoral Reform, Japan v. Italy and New Zealand 16 Int. Pol. Sci. Rev. 1 (1995); Takayuki Sakamoto, Explaining Electoral Reform: Japan v. Italy and New Zealand, 5 Party Pol. 419 (1999). ${ }^{29}$ Dennis Pilon, Renewing Canadian Democracy: Citizen Engagement in Voting System Reform (March 2002).

30 See, e.g., Keith Jackson and Alan McRobie, New Zealand Adopts Proportional Representation (1998); Denemark, supra note 17; Andrew Geddis and Caroline Morris, "All is Changed, Changed Utterly?"-The Causes and Consequences of New Zealand's Adoption of MMP, 32 Fed. L. Rev. 451, 454-46 (2004); Nagel, supra note 18; Jack Vowles, The Politics of Electoral Reform in New Zealand, 16 Int. Pol. Sci. Rev. 95 (1995); Hon. Sir John Wallace, Reflections on Constitutional and Other Issues Concerning our Electoral System: The Past and the Future, 33 Victoria Univ. Wellington L. Rev. 297 (2002); see also infra text accompanying note 62 (defining a mixed-member proportional system). Although Italy, Japan, and New Zealand all switched voting systems in 1993 and 1994, I focus here on New Zealand because, like the United States, it had a long history of using a first-past-the-post election system. Further, New Zealand had an ad-hoc electoral reform commission that operated in political conditions that seem closer to everyday American politics than those that existed in Italy, see Patrick Dunleavy and Helen Margetts, Understanding the Dynamic of Electoral Reform, 16 Int. Pol. Sci. Rev. 9, 11 (1995), and perhaps than those that existed in Japan. See generally, Sakamoto, supra note 28.

31 See, e.g., Pilon, supra note 29, at 18, 19, 23, 27, 28, 39, 47; Dunleavy and Margetts, supra note 30, at 12.

32 Only Barkow has self-consciously challenged the value of political independence. Elmendorf, for instance, places great emphasis on the value of independence, although that emphasis may stem in part from the fact that his proposal for advisory commissions already presumes that the commission's ability to get something done depends on its ability to negotiate the political process. Pilon does not directly address the issue of independence, but his paper certainly has much praise for the role independent commissions have played in achieving reform. The same is true of the scholarship on New Zealand's shift to a semiproportional system. 
these studies comport sufficiently with common sense and more well-established literatures that they provide a useful basis for some initial speculation.

The sounding board. The first reason that political inoculation serves a useful purpose in furthering reform stems from the role that legislators and other political elites can play as a sounding board. Reform commissionswhether they are made up of citizens or technocrats-may have a tin ear about the political viability of their proposals. They may not know what types of proposals are likely to have political legs, let alone how best to frame the proposals put forward. One remedy for that problem is to create a mechanism for introducing a dose of political reality into the decision making process.

Rachel Barkow, for instance, notes that sentencing commissions that include some legislative members succeed in part because those members can "alert the commission to political concerns." 33 One of the most successful sentencing commissions in the United States has been Minnesota's, which was chaired by a "skilled lobbyist" who "kept close contact with the legislature to lobby on behalf of the Commission and its work product." ${ }^{34}$ Moreover, because the Minnesota commission was determined to understand the lay of the political landscape, it did not merely issue a general notice for public hearings and listen to whomever turned up, but "proactively targeted interested groups and individuals and used direct mail to encourage their participation." 35 Thus, rather than treating citizens as an undifferentiated mass, the commission treated them as potential members of interests groups that might play a role in whether reform would succeed.

The political work of the Minnesota commission paid off, as the commission was able to convince legislators to adopt a variety of reforms. Most interestingly, the commission found a politically viable hook to convince legislators to reduce sentences: resource constraints and the costs imposed by an overpopulated prison system. Unlike several of its independent counterparts, the Minnesota commission then focused its energies on producing prison population impact statements, which turned out to have a discernible effect on legislative conduct. ${ }^{36}$

Consider also the success of the U.K.'s Electoral Commission, which uses pilot projects and opinion research to test the political waters before committing to a particular reform proposal. For instance, the Commission conducted extensive research about the views of the British public on campaign finance. That research disclosed a level of public confusion and ambivalence about public financing that led the Commission to adopt a more incremental approach to campaign finance reform that fit well with most citizens' sense of how public financing should work. ${ }^{37}$

Finally, the Royal Commission on the Electoral System, widely credited as one of the catalysts for New Zealand's 1993 decision to switch election systems, ${ }^{38}$ also took politics into account during its decision making process. For example, the membership of the Royal Commission was deliberately designed to be politically insulated and thus did not include any members of Parliament (MPs) or former members of Parliament. ${ }^{39}$ But precisely "[b]ecause the Commission included no MPs, it made a particular effort to hear the views of a range of current and past MPs, together with groups of MPs selected by each of the three political parties represented in the House of Representatives and the Maori MPs." 40

33 Barkow, supra note 18, at 719. Another benefit to this strategy is that legislators, in turn, get exposed to perspectives and viewpoints that do not otherwise dominate the political discourse (assuming the commission is composed of a sufficiently diverse membership). Id. at 801 . 34 Id. at 773 .

${ }^{35} \mathrm{Id}$. For additional accounts of the success of the Minnesota commission, see Richard S. Frase, Implementing Commission-Based Sentencing Guidelines: The Lessons of the First Ten Years in Minnesota, 2 Cornell J. L. \& Pub. Pol'y. 279 (1993); Dale G. Parent, What Did the United States Sentencing Commission Miss?, 101 Yale L.J 1773 (1992); Susan E. Martin, "The Politics of Sentencing Reform: Sentencing Guidelines in Pennsylvania and Minnesota," in The National Academy of Sciences, Research on Sentencing: The Search for Reform 265 (Blumstein et al., eds. 1983).

36 Barkow, supra note 18 , at 776-77.

${ }^{37}$ Elmendorf, supra note 13, at 1439-40.

38 See, e.g., Denemark, supra note 17, at 71.

39 Jackson and McRobie, supra note 30, at 104; Wallace, supra note 30, at 298.

40 Jackson and McRobie, supra note 30, at 104. 
Elites as advocates and agenda setters. The need for allies provides a second reason why political inoculation ought to be appealing to someone concerned with ensuring that democratic support for reform is broad and deep. Once a commission decides on a reform proposal, the next step is to get it implemented. And what has taken place during the decision making process will often affect what allies the commission will have during the implementation stage. Here again, those decision making bodies that are able to appeal to at least some legislators, party officials, or special interest groups encounter greater success in generating political energy behind reform. ${ }^{41}$

Barkow, for instance, notes that legislative members of sentencing commissions are not merely good sounding boards, but "provide ready-made advocates for the commission's conclusions when the legislature as a whole debates its proposals." 42 Similarly, Elmendorf describes the admittedly self-interested-but highly successful-efforts of the House of Lords, the Liberal Democrats, and the Conservative Party to publicize and advocate the reform proposals made by the U.K.'s Electoral Commission. ${ }^{43}$ And those who have studied reform efforts in New Zealand often emphasize the importance of such things as "independentminded" politicians, and the self-interested efforts of the minority party to use electoral reform as a weapon against the majority party. ${ }^{4}$

No one should be surprised that the support of political elites matters in this context. Elites not only have access to the media and other avenues for communicating with citizens, but they may also be skilled at framing issues and raising awareness. Indeed, a well-established literature documents the ways that interest groups and party leaders can shape public opinion by offering cues to voters and framing an issue effectively. ${ }^{45}$ Consistent with this longstanding literature, the empirical work on independence suggests that the reform commissions that have proved most successful in persuading the public to back a reform proposal have been able to harness the skills of those elites in the service of reform.

Indeed, one of the lessons we can draw from the reform experiences of other countries is that reform proposals often gain the most traction when they become a stick used by the opposition party to beat up the party in power. ${ }^{46}$ It is not the most high-minded use to which reform proposals can be put, but it is effective. ${ }^{47}$ Con-

${ }^{41}$ Disillusionment with politics or political parties can, of course, undermine the effectiveness of this strategy. In New Zealand, for instance, hostility toward politicians and the political system ran so high that one former prime minister "quipped that the only way the major parties could stop [reform] was to endorse it." Nagel, supra note 18 , at 526 .

42 Barkow, supra note 18 , at 719, 802-03.

43 Elmendorf, supra note 13, at 1396-1404.

44 Pilon, supra note 29, at 22-23; see also Denemark, supra note 17, at 89, 91-93; Vowles, supra note 30, at 104-05.

45 See, e.g., Arthur Lupia and Mathew D. McCubbins, The Democratic Dilemma: Can Citizens Learn What They Need to Know (1998); William H. Riker, Liberalism Against Populism: A Confrontation Between the Theory of Democracy and the Theory of Social Choice (1982); Paul M. Sniderman et al., Reasoning and Choices: Explorations in Political Psychology (1991); John R. Zaller, The Nature and Origins of Mass Opinion (1992); Julie L. Andsager, How Interest Groups Attempt to Shape Public Opinion with Competing New Frames, 77 Journalism \& Mass Comm. Q. 577 (2000); Elizabeth R. Gerber and Justin H. Phillips, Development Ballot Measures, Interest Group Endorsements, and the Political Geography of Growth Preferences, 47 Am. J. Pol. Sci. 625 (2003); Jeffrey A. Karp, "The Influence of Elite Endorsements in Initiative Campaigns," in Citizens as Legislators: Direct Democracy in the United States 109 (Bowler et al., eds. 1998); James H. Kuklinski and Norman L. Hurley, "It's a matter of interpretation," in Political Persuasion and Attitude Change (Mutz et al., eds. 1996); Arthur Lupia, Shortcuts Versus Encyclopedias: Information and Voting Behavior in California Insurance Reform Elections, 88 Am. Pol. Sci. Rev. 63 (1994); Michael A. Lewkowicz, The Effectiveness of Elite Cues as Heuristics in Proposition Elections, 34 Am. Pol. Res. 51 (Jan. 2006); Jeffrey J. Mondak, Source Cues and Policy Approval: The Cognitive Dynamics of Support for the Reagan Agenda, 37 Am. Pol. Sci. 186 (1993); Richard G. Niemi and Anders Westholm, Issues, Parties and Attitudinal Stability: A Comparative Study of Sweden and the United States, 3 Electoral Stud. 65 (1984); Thomas E. Nelson and Donald R. Kinder, Issue Frames and Group-Centrism in American Public Opinions, 58 J. Pol. 1055 (1996); Thomas E. Nelson, Policy Goals, Public Rhetoric, and Political Attitudes, 66 J. Pol. 581 (2004); Lee Sigelman, Voting in Gubernatorial Succession Referenda: The Incumbency Cue, 51 J. Pol. 869 (1989). But see James N. Druckman and Kjersten R. Nelson, Framing and Deliberation: How Citizens' Conversations Limit Elite Influence, 47 Am J. Pol. Sci. 729 (2003) (suggesting that discussions among citizens of diverse viewpoints can reduce the effect of framing on individual attitudes).

46 See, e.g., Vowles, supra note 30, at 103 (describing the National opposition's use of New Zealand's Royal Commission's reform recommendations to attack Labour, the party in power); $i d$. at 105 (describing minor parties' support for reform); Elmendorf, supra note 13, at 1396-1404 (describing use of Royal Commission reports to score points off of the Labour Party by its political enemies). It is even more useful in this regard when the parties switch 
sider, for instance, the role that opposition parties in Great Britain and New Zealand have played in publicizing the proposals of its advisory electoral commission and shaming the majority party into supporting electoral reform. ${ }^{48}$

In sum, a little bit of politics seems to go a long way in facilitating the success of reform efforts generated by electoral reform commissions. At some point, most commissions seeking reform at the intersection of law and politics must wade into the political swamp. What the limited empirical literature on this topic suggests is that it is useful for these decisionmakers to have been inoculated against some of the more serious diseases circulating around that terrain before plunging ahead.

Public education as an alternative to inoculation? One might think that a privately funded or state-funded public education campaign, not political inoculation, is the solution for pushing reform through the political process. After all, if the problem is that the public requires information and cues about reform proposals, why not give the electoral reform commission the chance to oversee an education campaign in order to bypass self-interested elites, allowing the educational campaign to obviate the need for the sorts of cues that political parties usually generate? One such example is the public education campaign funded by the New Zealand government prior to the country's decision to switch voting systems. A well-funded and intelligently run public education campaign might do much to help the cause of reform.
Here again, however, politics rears its ugly head. The main problem with this argument is that the practical difficulty remains-a legislature that opposes reform is hardly likely to offer an adequate educational campaign in reform's favor. New Zealand's public education campaign was quite rare in scope and design. ${ }^{49}$ And even that campaign was thought by some to be underfunded ${ }^{50}$ and so tightly circumscribed by legislative mandates (the campaign was required to be "objective[]" and present only the "facts") that it had little effect on the public. ${ }^{51}$

More importantly, even if a campaign is funded privately, a public education campaign cannot transform a politically unpopular proposal into a popular one. Indeed, one would guess that political inoculation would be as important for a successful public education program as any other part of the reform process, as the efficacy of an educational campaign would depend on framing, understanding the preferences of voters, and having a viable political idea to promote. ${ }^{52}$ An educational campaign is a powerful tool in politics, but it is only one of them and seems an inadequate shield against the double-edged sword of independence.

\section{INOCULATING WITHOUT INFECTING: STRIKING THE BALANCE BETWEEN INDEPENDENCE AND POLITICS}

Even if one is convinced that political inoculation is a useful strategy for electoral reform

san body"). Further, a great deal of politicking was necessary before the major parties were willing to create an adequate educational program, and political elites played a key role in pushing reform. Pilon, supra note 29 , at 47.

50 Jackson and McRobie, supra note 30, at 262.

51 Vowles, supra note 30, at 109; but see Nagel, supra note 18 , at 526-27 (arguing that the public education campaign "helped to produce a remarkably high level of public understanding about electoral mechanics"); Pilon, supra note 29 , at 47 (offering a positive assessment of the campaign). 52 See, e.g., Shaun Bowler and Todd Donovan, Do Voters Have a Cue?: Television Advertisements As a Source of Information in Citizen-Initiated Referendum Campaigns, 41 Eur. J. Pol. Res. 777 (2002) (finding that government education programs work especially well when they provide cues to voters, including information about elite endorsements). 
commissions, a more difficult question remains: how to inoculate such commissions against politics while avoiding the risk of a serious infection. After all, one could as easily write an essay entitled "the double-edged sword of politics" and point out that electoral reform commissions completely infected by politics are unlikely to achieve reform or inspire democratic energy within the polity. A commission's give-and-take with politicians might unduly water down any reform that is passed. A commission might pay so much attention to politics that it loses the patina of independence that gave it standing to speak in the first place. There is obviously a balance to be struck here, a task that will depend on context and a set of empirical and normative questions that are not fully fleshed out in this article. The purpose of this article is merely to suggest that the balance may have tipped too heavily in favor of independence; a full-blown analysis of what an appropriate inoculation strategy might look like for both types of institutions is beyond its scope. Nonetheless, let me offer a few comparative observations about technocratic and citizen-based reform commissions in Section II.A before turning to the British Columbia Citizens' Assembly as a case study for working through some of these problems in Section II.B.

\section{A. Choosing a robust site for inoculation: Technocrats $v$. citizens}

In thinking about how to strike the proper balance between political infection and political quarantine, it is clear that one's inoculation strategy must be tailored to the type of institution in question. If one is concerned about whether reform proposals will get passed, expert commissions and citizens' assemblies enter the political fray with different strengths and weaknesses, and those strengths and weaknesses should affect our assessment of whether inoculation is necessary and how great are the risks of infection. Because the advantages associated with technocratic commissions seem obvious (presumably the reason why academics and reformers so often recommend them), I will dwell a bit more on the underappreciated justifications for thinking that citizens' assemblies represent a fairly hearty institutional specimen for political inoculation.
1. Heuristics and institutional vulnerabilities: Expertise v. the voice of the people. One common strength shared by expert commissions and citizens' assemblies as they negotiate the terrain of everyday politics is that each offers a useful heuristic for reformers to deploy in political debate. One of the problems in getting reform passed is that the party in power will almost always oppose reform, and voters are likely to take their cues about reform proposals from party leaders. Further, opponents of reform have two ready-made strategies for framing their opposition: (1) those supporting reform are "sore losers" and motivated by partisanship (that is, reformers are too infected by politics to be trusted), and (2) reformers are elitist, antidemocratic, or naive (that is, reformers are too quarantined from politics to be trusted).

EXPERT COMMISSIONS. The technocratic commission, of course, offers a particularly useful cue for avoiding the first kind of accusationthat a reform proposal is motivated by a partisan purpose. In common parlance, expertise implies neutrality. Further, people tend to defer to experts in sorting through complicated issues like electoral reform. That expertise gives technocratic commissions an important card to play in the game of politics, perhaps overcoming inertia or resistance that might otherwise exist regarding a particular policy proposal.

The danger for expert commissions is that they remain quite vulnerable to the second type of attack-the claim that they are antidemocratic or out of touch. And it is not hard to imagine the reality matching up with the stereotype. To be sure, expert commission members will presumably enjoy the advantages of being repeat players in the political process (especially if the commission members themselves serve multi-year terms). One might even hope that experts on elections, in particular, would be more savvy about politics than their counterparts elsewhere. Nonetheless, expertise can be a handicap in negotiating the political process. There remains a significant distance between studying and playing the game of politics, and the incentive structures within the academy may render some experts out of touch with day-to-day realities. Further, technocrats may know too much about arcane election issues to generate politically viable reform proposals; 
being deeply steeped in a professional culture can give one a tin ear to politics and prevent decision makers from being sufficiently flexible in their approach.

Under such circumstances, an inoculation strategy should prove useful to technocratic commissions. Experts need information about how nonexperts think and vote to assess what kinds of reform proposals might fly. By introducing a little bit of everyday politics into the discussion, a commission can temper its technocratic impulses with a bit of political realism.

Citizens' Assemblies. Citizens' assemblies enjoy a different set of advantages and handicaps in entering the political fray than expert commissions possess. A citizens' assembly has the potential to provide a powerful cue to voters, one likely to be useful in overcoming both of the conventional challenges to electoral reform. That is because it is difficult to accuse a randomly selected assembly of being either partisan sore losers or anti-democratic. To the contrary, one would expect the blessing of a citizens' assembly to function like the democratic version of the Good Housekeeping Seal of Approval. After all, it seems to represent something extraordinarily elusive in politics-the genuine voice of the people. Politicians are likely to be fairly reluctant to accuse everyday citizens of political taint or question an assembly's democratic credentials.

Nonetheless, citizens remain vulnerable to at least one type of challenge from those opposed to reform: inexperience. ${ }^{53}$ And, as with expert commissions, one can imagine the justifications for such an accusation. After all, most citizens lack expertise in election reform and have had little experience with the political process, both of which could undermine the chances that they will succeed in the political fray. We also might expect citizens to be less politically surefooted than their technocratic counterparts.

Here, again, political inoculation could prove to be a useful strategy. Consultation with old political hands could help citizens avoid beginner's mistakes. A bit of cold political realism might temper overly enthusiastic or idealistic decision makers, or at least help channel their enthusiasm in politically sensible directions.

INOCULATION STRATEGIES. What would inoculation look like in practice? As an informal mat- ter, reform commissions could seek out interaction with legislators and seasoned reformers, or engage in polling and small-scale experimentation to discern the political viability of particular proposals. There are also numerous formal institutional tweaks that might help inoculate a reform commission. For instance, a reform commission's membership might include legislators or party leaders. Or the commission might float trial balloons-pilot projects or tentative proposals to gauge the level of support for a particular idea.

Which inoculation strategy makes the most sense will depend on the institution. For instance, given that citizens' assemblies (at least those we've seen thus far) tend to be quite large, the addition of a single legislative member may be less useful than it would be on expert commissions, which are usually smaller. Similarly, polling and focus groups might be more important for expert commissions if we think of the citizens' assembly as something akin to a built-in focus group.

2. Inoculating without infecting. One might object, however, that such concessions to everyday politics risk eliminating precisely what makes such each type of electoral commission special: neutral expertise (in the case of technocratic commissions) and authenticity (in the case of citizens' assemblies). The risk is a genuine one. There are nonetheless good reasons to think that both types of institutions are well-suited to ward off the infection of politics in the long term.

As to expert commissions, the fact that its members are part of what we might call a professional guild may make them less vulnerable to the dangers of infection (and thus able to withstand a healthy dose of politics in the decision making process). Technocrats answer to a set of professional norms generated outside of the political process, so they should be less likely to succumb to political pressures than those without such an anchor.

Though citizens' assemblies lack such a constraint, they, too, seem fairly able to withstand a dose of everyday politics. After all, the odds

\footnotetext{
${ }^{53}$ For an example of such an attack on the only citizens' assembly to have taken place thus far, see infra note 70 .
} 
are fairly steep that a randomly drawn group of citizens will be any more receptive to the appeals of self-interested legislators than the rest of the polity. It is with good reason that political theorists have long valued randomness as a strategy for distributing political power. ${ }^{54}$ It is neutral, thus depriving the state (or, here, legislators) of the power to appoint, one of the most common strategies for influencing agency decisions ex ante. That seems especially true when one considers that the coins of the realm in a citizens' assembly are not money or power, but time and a willingness to participate. ${ }^{55}$

Further, if we imagine a permanent citizens' assembly or one that convenes every five or ten years, ${ }^{56}$ it is not only randomness that will help ward off political infection, but episodic turnover (given that citizens are volunteering their time to serve, multi-year terms seem impractical). Regular turnover eliminates the worry that assembly members will get too cozy with political interests, as the sort of repeat interactions and long-term ties that facilitate capture would be quite difficult under such circumstances. ${ }^{57}$

The combination of a random draw and episodic service also offers a built-in mechanism for reflection and fine-tuning for the citizens' assembly. Each new assembly has an opportunity to take a different tack than the assembly before. Episodic service all but forces the new assembly to reflect on the record of its predecessor, and it reduces the risk associated with one set of decision makers becoming overcommitted to its own, unsuccessful strategy (be it the route of quarantine or infection).

Finally, in the long run, both expert commissions and citizens' assemblies have significant incentives to strike the right balance between infection and quarantine. ${ }^{58}$ If such institutions live up to their promise-if they truly offer an expert's view or genuinely reflect the people's will-they will not be the lone voice of reform. As the New Zealand reform experience suggests, the decisions of a commission can often provide a rallying point for reform-minded organizations to generate political energy. ${ }^{59}$ Further, political entrepreneurs of all stripes would recognize the power associated with the imprimatur of a wellrespected reform commission. They are likely to vie for its "blessing" and throw their support behind as many of its proposals as they could. ${ }^{60}$
The ability of both types of commissions to leverage this kind of power, however, depends on perception - the perception of either neutral expertise or authenticity. Too little politicking,

54 See, e.g., Neil Duxbury, Random Justice: On Lotteries and Legal Decision-Making (1999); Jon Elster, Solomonic Judgments: Studies in the Limitations of Rationality 72-122 (1989); Bernard Manin, The Principles of Representative Government 8-84 (1997). On the use of the lottery to choose office holders and make political decisions, see Bruce Ackerman, Social Justice in the Liberal State, 285-89, 298 (1989) (discussing a "responsive lottery" as an alternative to majority rule); Elster, supra, at 78-86; Manin, supra, chs. 1 and 2; Duxbury, supra, at 26-34; John Burnheim, Is Democracy Possible? An Alternative to Electoral Politics 9-12, 106-24 (1985); Dennis Mueller et al., Representative Democracy via Random Selection, 12 Pub. Choice 57 (1972); Richard Thaler, Illusions and Mirages in Public Policy 73 Pub. Int. 60, 72 (1982) (discussing congressional committees); Robert Weissberg, Collective v. Dyadic Representation, 72 Am. Pol. Sci. Rev. 535, 544 (1978); Akhil R. Amar, Note, Choosing Representatives by Lottery Voting, 93 Yale L.J. 1283 (1984).

${ }^{55}$ Here again, there is a potential downside to this design feature. Pure randomness is not possible in this context, as the time commitment involved requires some measure of self-selection by participants. It is quite possible that the people willing to serve on a citizens' assembly are not representative of the people generally. For instance, an assembly might attract more reform-minded zealots than a truly random draw. And randomness itself, of course, can generate decision making bodies dominated by those with outlier political views. See Heather K. Gerken, Second-Order Diversity, 118 Harv. L. Rev. 1099 (2005).

56 There are, of course, costs and benefits associated with permanence. On the one hand, a permanent assembly tasked with handling a variety of electoral-reform issues would have ample opportunity to build its reputational capital. On the other hand, constant revision of electoral rules could lead to unnecessary instability and uncertainty in the political process, focusing the attention of political parties on fights over the rules of competition rather than substantive politics. Further, constant battles over electoral reform might inure citizens to these debates, thus reducing the level of political support for change.

${ }^{57}$ Episodic service may also be a source of weakness for the assembly model, however, as it means that participants will not have a chance to build on experience and hone their political skills. Thus, some sort of inoculation may be essential for a citizens' assembly precisely to provide a needed corrective against political naïveté.

58 Elemendorf makes a similar point in his work on advisory commissions. See Elmendorf, supra note 13, at 1382-84, 1431-36.

${ }^{59}$ Denemark, supra note 17, at 88; Geddis, supra note 30, at 458; Jackson and McRobie, supra note 30, at 123-24; Nagel, supra note 18, at 526; Pilon, supra note 29, at 46-47. 60 Consider the impressive competition among U.S. politicians for the blessings of the 9/11 Commission or the Jersey Girls, who played such a prominent role in articulating the needs and desires of the families of $9 / 11$ victims in the wake of the attack. Elmendorf, supra note 13, at 1384. 
and each will be vulnerable to challenges that it is too isolated or too unrepresentative to warrant deference from voters. Too much politicking, and neither has something distinctive to offer to the debate. Put differently, commissions like these have a built-in sunset provision. The moment they lose the support of the citizenry-either because they failed to politic or they politicked too much-they lose their ability to affect the political debate.

At least for citizens' assemblies, ${ }^{61}$ there is more to the argument than the claim that it has the right incentives to strike an appropriate balance between political quarantine and political infection. Even if a citizens' assembly fails, we may see a different organization-one that does a better job of striking that balancerising to take its place. The tenor of the conversation, at least, will continue to change.

Here's why. Even if a citizens' assembly were to fail, the way that it would fail seems likely to generate new opportunities for grassroots influence on the political process. The mere existence of the institution changes the political terrain. That is because there are a limited number of strategies available for attacking an institution like a citizens' assembly. The debate seems almost destined to focus primarily on who genuinely speaks for the people. An effective attack would require one to point to a different institution that has standing to speak for the people. Thus, even if the assembly were to wade too deeply into the political swamp, other organizations would be able to contest the assembly's claim to authority.

\section{B. The British Columbia experience: A case study}

The generalities offered above, of course, are just that-generalities. Any prescription for inoculating an electoral reform commission requires a number of contextual judgments. To ground this analysis a bit, let me close by offering a case study of one such decision making body-the British Columbia Citizen's Assembly-and the ways in which inoculation might have been a useful strategy for helping the Assembly's reform proposal become a reality.

As noted above, the B.C. Citizens' Assembly was charged with considering whether the province's first-past-the-post system ought to be abandoned. The Assembly was drawn from a pool that was randomly selected from lists stratified by age, gender, and district. After the pool was winnowed down to those willing and eligible to take part, 158 members were drawn (one woman and one man from each district), with two members from the First Nations peoples then added to round out the group. The eleven-month, multi-stage deliberation process included a "learning phase" (consisting of presentations and small discussion groups), the "public hearing phrase" (50 public hearings, each attended by subsets of the assembly's membership, and an opportunity for written comments), and the "deliberation phase" (during which the Assembly came up with its recommendation). During the deliberation phrase, the Assembly narrowed down the choice of potential alternatives to a single-transferable vote (STV) system (which allows voters to rank candidates and uses those rankings to distribute votes among the candidates) and a mixed member proportional (MMP) system (which elects candidates using both single-member districts and proportional voting). The Assembly than endorsed STV over B.C.'s current system-a first-past-the-post, single-member districting system-by a substantial margin. ${ }^{62}$

The B.C. Assembly's proposal that the province switch to STV was then put on a provincial referendum, to be implemented if it garnered a "double majority": (1) more than $60 \%$ of the ballots cast province-wide, and (2) a simple majority in $60 \%$ of the province's ridings. The Assembly's proposal succeeded in gaining a majority in all but two of the

${ }^{61}$ It is more difficult to discern whether the creation of an expert commission has the same power to change political discourse. First, expert commissions are more common than citizens' assemblies and thus less likely to make a political splash. Second, the obvious grounds for challenging expert commissions-that they are antidemocratic or too insulated from everyday citizens-seem less likely to push toward a search for a "more" expert replacement.

62 The description in this paragraph was drawn from the official final report circulated by the organizers of the Assembly, Final Report, Making Every Vote Count: The Case for Electoral Reform in British Columbia (2005), available at <http://www.citizensassembly.bc.ca/resources/final. report.pdf $>$ (last visited Sept. 6, 2006). 
province's ridings but fell just short (about $58 \%$ ) of the supermajority vote requirement. ${ }^{63}$ The government has scheduled another referendum on the proposal for 2008 in the hope that public discussion will result in a more conclusive result. ${ }^{64}$

\section{Heuristics and institutional vulnerabili-} ties. As an initial matter, the Assembly provides some reason to think that citizens' assemblies offer a particularly intriguing model for reformers trying to navigate difficult political terrain. To begin, the British Columbia experience offers suggestive, albeit very limited, evidence of the potential power associated with citizen assemblies as vehicles for reform. One might think that is an odd conclusion given that the Assembly's proposal failed to pass. But even though its proposal did not garner the necessary $60 \%$ of the popular vote to pass, two facts stand out.

First, one cannot help but be impressed by the large number of citizens who voted for reform despite the absence of an adequate public education campaign or significant public debate. Part of the B.C. Assembly's success obviously stems from its agenda-setting power. Because the Assembly could place a proposal on the ballot, it was able to begin a conversation about reform in British Columbia that had not taken place before then.

But the power of the B.C. Citizens' Assembly, I suspect, went beyond the power that might have been wielded by a comparably situated independent commission of technocrats. After all, the Assembly had no money for a public education campaign, and political elites maintained a virtual radio silence about the issue; the combination might well represent the death knell for any initiative proposal. It therefore seems quite remarkable that approximately $58 \%$ of the B.C. citizenry-having received little or no information about the referendum ${ }^{65}$-were apparently willing to gamble on the reform proposal simply because the Citizens' Assembly had proposed it. Perhaps one can attribute the vote entirely to political cynicism-many B.C. voters preferred anything to the status quo. ${ }^{66} \mathrm{But}$ it is hard to ignore the possibility that the appearance of the words "Citizens' Assembly" on the ballot had an effect on voters' decisions.
Second, the nominally failed effort of the B.C. Assembly continues to have a remarkable effect on B.C. politics. The fact that the referendum garnered a significant majority of votes made it all but impossible for incumbent politicians to ignore the proposal. As a result, the Lieutenant-Governor recently announced that the government would take up the issue again and run a second referendum on the proposal. Interestingly, in making this announcement, the governing party was extremely cautious about creating the appearance that it was displacing the Assembly's proposal with a different reform idea. As the Lieutenant-Governor herself emphasized, the governing party "does not accept that the 79 members of [B.C.'s] assembly are any better qualified than the . . . members of the Citizens' Assembly" to "choose the best electoral model." 67 Instead, the Lieutenant-Governor highlighted the government's respect for the Assembly's "citizen-centered" model and attributed the failure of the referendum to the Assembly's inability to provide specific information as to how boundaries under [the Assembly's proposed] system would be drawn. ${ }^{68}$ Indeed, even as the LieutenantGovernor announced important changes to the Assembly's proposal, she insisted that her party was merely hewing to the Assembly's plan-just "taking it to its ultimate conclu-

63 Tom Fletcher, "Electoral Reformers Pressing Ahead," Williams Lake Trib. (July 19, 2005).

${ }^{64}$ Iona Campagnolo, Speech from the Throne, Opening of the First Session, Thirty-Eighth Parliament, British Columbia (Sept. 12, 2005).

65 Wendy Stueck, "STV gets high-profile boost," The Globe and Mail, May 9, 2005, at S1 (noting that April poll "found that nearly half of the voters in British Columbia know 'nothing at all' about STV").

66 See Jeffrey Simpson, "A vote for something-or just anything at all?" The Globe and Mail, May 21, 2005, at A19 (offering this explanation); see also Ratner, supra note 11, at 24 (prior to the vote, noting widespread "public disenchantment with parliamentary politics"). That seems to have been the case in New Zealand, for instance, where $85 \%$ of New Zealand's voters cast a ballot against the existing first-past-the-post election system due to "overwhelming disillusionment with politicians and the political system," Nagel, supra note 18, at 526, although there, too, an electoral reform commission had endorsed an alternative system.

${ }^{67}$ Campagnolo, supra note 64 , at 26.

${ }^{68} \mathrm{Id}$. at $26-27$. 
sion." 69 The governing party also gave in to the demands of the Assembly's alumni by promising adequate funding for an education campaign.

The fact that the Assembly's failed attempt to pass its proposal through a referendum induced this level of political pussyfooting by the party in power is quite suggestive. It confirms how difficult it is for partisan elites to compete with a citizens' assembly on authenticity grounds and thus how hard it is for them to ignore or challenge its proposals. ${ }^{70}$ Whether the now-disbanded B.C. Assembly can keep the pressure on politicians-and what effect elite endorsements and challenges will have on the next part of the story-remains to be seen.

2. Inoculating without infecting. The obvious question, of course, is whether there was anything that might have improved the chances that the Assembly's proposal would have passed in the first place. The Assembly's proposal won a surprising number of votes given the constraints that existed, but would it have been possible to do better? Although it is impossible to offer a precise diagnosis, there are reasons to think that, consistent with the inoculation hypothesis, the Assembly's failure came from engaging in too little politicking, not too much.

There appears to be no evidence that the Assembly's STV proposal failed to pass the $60 \%$ threshold because the Assembly engaged in too much politicking. Press reports contain no accusations that assembly members were improperly influenced by political considerations. To the contrary, one of the rare attacks on the assembly suggested that it was not sufficiently in touch with the needs of the people, arguing that the Assembly's members were being led by the nose by a bunch of out-of-touch, overly idealistic academics. ${ }^{71}$

Moreover, the way the assembly was run suggests that its problem was more likely to stem from quarantine than infection. Legislators and the political parties remained quite distant from the decision making process. With the exception of the Greens, the parties seem to have done relatively little lobbying during the process (and the Greens' strategy proved to be quite unwelcome to the Assembly's partici- pants $^{72}$ ). Moreover, neither legislators nor party leaders helped in vetting the proposals circulating around the Assembly.

Consider a few ways in which an inoculation strategy might have aided passage of the B.C. Assembly's proposal. First, the Assembly might have paid greater attention to the political viability of its proposed change. According to the Assembly's final report, although STV emerged as the clear choice among those deliberating, other ideas were available to Assembly members, including MMP. ${ }^{73}$ What would have happened if Assembly members had vetted their top two or three preferred alternatives at an early stage in their deliberations, either by talking to seasoned politicians or reformers or by using polls to ascertain how the average citizen (who, unlike Assembly members, had not spent almost a year thinking about electoral reform) reacted to each alternative? Perhaps it would have had no effect on the decision of the Assembly. Or perhaps its members would have chosen a different proposal, one that would have been easier to explain or promote to the public.

For example, one of the evident handicaps faced by STV proponents was the fact that the system was used by only a few, small nations across the globe. Had the participants focused more on the next step in the reform processthe need to convince a supermajority of the electorate to vote for change - they might have

${ }^{69} \mathrm{Id}$. at 27.

${ }^{70}$ As one reporter observed during the debate over the referendum, "most of those who joined the debate over BC-STV were careful to pay their respects to the citizens, even as they disagreed with their recommendations." Vaughn Palmer, The Vancouver Sun, May 20, 2005, at A3. ${ }^{71}$ See, e.g., Norman Spector, Lies and truth on the campaign trail, Times Colonist (Victoria), April 29, 2005, at A14 (arguing that an "unrepresentative group of British Columbians" are using hard working B.C. natives as the "mice in an experiment designed by well-meaning people who spent too much time with tenured university professors").

72 Supra note 11.

${ }^{73}$ Final Report, supra note 62 , at 13 (showing that the MMP proposal was initially favored by about $1 / 5$ th of Assembly members); Les Levne, Comment, Politicians should keep their hands off, Times Colonist, May 21, 2005, at A10 (noting that a "mixed-member system" - apparently favored at least by the Greens-"'was never far from the [assembly members'] minds"). 
chosen to endorse MMP, a widely used system adopted by a number of major Western democracies and used by roughly half a billion people. ${ }^{74}$ Its political saleability is evidenced by the fact that it was chosen by three of the countries to have changed their election systems most recently (Italy, New Zealand, and Japan), and it is often described by academics as a "middle ground" 75 or "best-of-both-worlds approach."76 By way of contrast, consider the fact that New Zealand's successful electoral reform commission endorsed MMP over STV in part because of the likelihood that MMP would "secur[e] popular support."77

Similarly, we might speculate as to whether the Assembly might have benefited from more high profile support during the referendum process. ${ }^{78}$ As noted above, there is extensive empirical evidence that voters use cues-like endorsements from prominent party leaders and officials-in evaluating an issue. ${ }^{79}$ But B.C. voters were not given many cues by political elites-at least by political elites who favored reform. That is not surprising given that the Assembly ultimately chose a proposal that was disfavored by the governing party and its primary opposition. ${ }^{80}$ Given how difficult it is for political parties to attack citizens' assemblies, ${ }^{81}$ British Columbia's major parties seemed to have used the second-most effective weapon at their disposal—strategic silence-and thus deprived voters of much-needed information.

Indeed, the B.C. Assembly's proposal was so unpopular among B.C.'s political elites that even the Greens-the one party that ought to have been most enthusiastic about electoral reform-preferred a different plan. ${ }^{82}$ As a result, the Greens were the sole party to endorse the Assembly's proposal, and they did so only after their leader had spoken strongly in favor of a different plan. ${ }^{83}$ Individual political elites and interest groups also kept their distance; even Gordon Campbell, the Assembly's primary architect, failed to endorse its proposal. ${ }^{84}$ And it appears that the only special interest group to offer an endorsement, the Vancouver Board of Trade, came out against the proposal.

Here again, an examination of the path not taken might be useful. As noted above, reform proposals are often most successful when they can be used by the minority party to attack the party in power. ${ }^{85}$ We know, of course, that the Greens in B.C. were supportive of a move toward greater proportionality (and, as a minority party, had every reason to desire it). By choosing a proposal that most Greens, including the party's leader, disfavored, the Assembly may have deprived itself of an important ally. Perhaps as a result, according to one observer, "no one of political significance is championing a radical change begging for an evangelist." 86

It is, of course, impossible to prove that political inoculation-the path not taken by the

${ }^{74}$ Nagel, supra note 18 , at 525.

75 Norris, supra note 12 , at 4 .

${ }^{76}$ Nagel, supra note 18, at 525 (quoting reform advocate Matthew Cossolotto).

77 Denemark, supra note 17 , at 88.

78 There are, of course, potential costs associated with such support. If too many politicians associate themselves with an assembly and its proposals, it might lose its patina of legitimacy because it is too closely associated with those in power.

79 Supra note 44 . We even saw use of this strategy by an opponent of STV, who relied on statements made against STV by two former party leaders, former NDP premier Dave Barrett and former Social Credit premier Bill Bennett: "In their long political careers, former premiers Bill Bennett and Dave Barrett $\mathrm{H}$ have never agreed on anything. Yet neither believes STV would be good for B.C." Norman Spector, "Voting 'no' to BC-STV and hoping for better," The Vancouver Sun, May 13, 2005, at A19.

80 Vaughn Palmer, "Other Liberals not as high as Campbell on STV," The Vancouver Sun, May 11, 2005, at A3.

81 Supra text accompanying notes 67 to 69.

82 It is possible that, as seems to have been the case in New Zealand, supra note 41, anti-party sentiment might be so strong that the support of at least the two major parties might have undermined support for the Assembly's proposal. Even in New Zealand, however, the minor parties' support for reform was thought to have helped its passage. See Denemark, supra note 17, at 89, 91-93; Vowles, supra note 30, at 104-05.

83 Palmer, supra note 80 (indicating that neither the B.C. Liberals nor NDP endorsed the proposal); Craig McInness, "If STV fails, it will be years before we get change," The Vancouver Sun, May 12, 2005, at A15 (noting that the Green party's leader was "officially neutral" on the proposal); Jeffrey Simpson, "A vote for something-or just anything at all?" The Globe and Mail, May 21, 2005, at A19 (noting survey results indicating that "only 32 percent of voters could even name STV . . . [and] the majority didn't even know what it was").

84 Palmer, supra note 80 (noting Campbell's neutrality and observing that even one week before the referendum that the Dean of the University of Vancouver Law School was "one of the few high profile members of the Liberals or New Dem-ocrats who have come out in favour of STV"). 85 Supra text accompanying notes 43,44 , and 46.

${ }^{86}$ James Travers, "B.C.'s proposed electoral system just won't work," The Record, April 28, 2005, at A9. 
B.C. Assembly-would have led to a successful referendum vote in 2005. Striking the right balance between political quarantine and political infection is a difficult task. Nonetheless, it is worth at least considering whether political inoculation might prove to be a useful strategy for those proposing and designing such assemblies in the future.

\section{CONCLUSION}

Independence is a popular idea among academics and policymakers interested in electoral reform. Rather than offering the conventional response to calls for independence-the assertion that independence cannot be had-this article considers instead whether one can have too much of a good thing. Its modest claim is that we need not choose between political quarantine and political infection. There exists a middle ground in the design of electoral reform commissions: political inoculation. Introducing a little bit of politics into a reform commission's decision making process may inoculate its proposals against the political fray. The evidence at this point is too limited to draw any firm conclusions. But given that conventional wisdom pushes so forcefully in the direction of the pure independence model, it is worth considering whether inoculation might help electoral reform commissions live up to their name.

Address reprint requests to: Heather K. Gerken Yale Law School 127 Wall Street New Haven, CT 06511

E-mail: heather.gerken@yale.edu 